\title{
Invasive properties of fibroblast-like synoviocytes: correlation with growth characteristics and expression of MMP-1, MMP-3, and MMP-10
}

\author{
T C A Tolboom, E Pieterman, W H van der Laan, R E M Toes, A L Huidekoper, \\ R G H H Nelissen, F C Breedveld, T W J Huizinga
}

See end of article for authors' affiliations

Correspondence to: Professor T W J Huizinga, Leiden University Medical Centre, Department of Rheumatology, C4-R, PO Box 9600,2300 RC

Leiden, The Netherlands;

T.W.J.Huizinga@LUMC.nl

Accepted

15 February 2002

\begin{abstract}
Background: Matrix metalloproteinases (MMPs) have a pivotal role in the destruction of cartilage in rheumatoid arthritis (RA), which is mediated by the fibroblast-like synoviocytes (FLS).

Objective: To examine the in vitro invasiveness of synoviocytes obtained from inflamed joints of patients with arthritis in relation to the expression of MMP 1-14, 17, 19, cathepsin-K, the tissue inhibitors of matrix metalloproteinases TIMP-1 and TIMP-2 by FLS.

Methods: FLS were derived from 56 patients ( 30 with RA, 17 with osteoarthritis (OA), and nine with avascular necrosis (AVN)). Invasive growth of FLS through an artificial matrix (Matrigel) was measured in a transwell system. The number of cells that migrated through the matrix were counted. Proliferation rate was determined by counting the FLS after seven days of culturing. Expression of MMPs, cathepsin-K and TIMPs was investigated with reverse transcriptase-polymerase chain reaction and related to the expression of a household gene, $\beta$-actin.

Results: FLS from RA showed greater invasive growth than FLS from OA and AVN. The median number of cells that grew through the matrix membrane was 4788 for RA, significantly higher than the number for OA, $1875(p<0.001)$ and for AVN, 1530 ( $p=0.014)$. The median rate of proliferation of RA FLS was 0.27 per day compared with OA 0.22 per day $(p=0.012)$ and AVN 0.25 per day, but there was no correlation between the rate of proliferation and invasive growth in vitro. FLS from RA and OA that expressed MMP-1, MMP-3, or MMP-10 were significantly more invasive (median number of invasive cells: 3835, 4248, 4990, respectively) than cells that did not express these MMPs (1605, $p=0.03$; $1970, p=0.004 ; 2360, p=0.012$, respectively). There was also a significant relationship between the expression of MMP-1 and MMP-9 and the diagnosis RA (both $p=0.013$ ). The expression levels of mRNA for MMP-1 and MMP-2 correlated with the protein levels produced by the synoviocytes as measured by an enzyme linked immunosorbent assay (ELISA).

Conclusion: FLS of RA invade more aggressively in a Matrigel matrix than OA and AVN FLS; this is not because of a higher rate of proliferation of RA FLS. The significant correlation between the expression of MMP-1, MMP-3, and MMP-10 and invasive growth in a Matrigel transwell system suggests that these MMPs play a part in the invasive growth of FLS obtained from patients with RA.
\end{abstract}

$\mathrm{R}$ heumatoid arthritis is a chronic disabling disease in which the progressive destruction of joints is an important characteristic. Hyperplasia and chronic inflammation of the synovial membranes characterise the disorder and eventually the synovial membranes invade deeply into the articular cartilage and bone. Activated fibroblast-like synoviocytes (FLS) in the lining layer of the synovium contribute significantly to this process. ${ }^{12}$ Synovial hyperplasia may be explained by an increased rate of proliferation or a decreased rate of apoptosis of FLS.

An increased expression of proliferation markers such as proliferating cell nuclear antigen, c-myc, and nucleolar organising region was seen in FLS from patients with rheumatoid arthritis (RA) compared with FLS from patients with osteoarthritis (OA). ${ }^{3}$ Therefore, it is possible that FLS of patients with RA show greater proliferation than FLS of patients with OA. However, as far as we know, no study has directly investigated the proliferation rate of FLS from patients with arthritis. Both increased proliferation and invasive growth characteristics may underlie joint destruction.

Using the SCID mouse co-implantation model of RA it has been shown that FLS of patients with RA attach to and invade normal human cartilage in vivo, whereas normal FLS do not invade normal human cartilage. ${ }^{24}$ Clearly, intrinsic features of RA FLS underlie this invasive behaviour. In this study, invasive growth is demonstrated in an in vitro Matrigel transwell system, enabling the analysis of a potential correlation between invasive growth and proliferation rate.

FLS are characterised by an up regulated expression of adhesion molecules and matrix degrading enzymes. Matrix degrading enzymes remove the extracellular matrix (ECM), providing space for FLS to invade. Matrix metalloproteinases (MMPs) are thought to be the most important matrix degrading enzymes in RA. This family of enzymes comprises 19 members, MMP1-3, 7-17, 19-21, and 23-24. MMPs can degrade a wide variety of components of the ECM, including the fibrillar collagens. In normal tissue, it is thought that the MMPs exist in balance with their inhibitors, primarily the tissue inhibitors of metalloproteinases (TIMPs). ${ }^{5}$ Another family of enzymes thought to have a significant role in the degradation of cartilage of RA are the cathepsins. Cathepsin-K,

Abbreviations: AVN, avascular necrosis; ECM, extracellular matrix; FCS, fetal calf serum; FLS, fibroblast-like synoviocytes; IMDM, Iscove's modified Dulbecco's medium; MLV-RT, murine leukaemia virus- reverse transcriptase; MMP, matrix metalloproteinase; OA, osteoarthritis; PBS, phosphate buffered saline; RA, rheumatoid arthritis; RT-PCR, reverse transcriptase-polymerase chain reaction; TIMP, tissue inhibitor of matrix metalloproteinase 
particularly, is found in the synovium of RA and at sites of synovial bone destruction. ${ }^{6}$

Therefore, in this study the expression of MMP 1-3, 7-14, 17, and 19, cathepsin K, TIMP-1 and TIMP-2 was investigated in FLS obtained from various patients and compared with the invasiveness of the FLS in an in vitro Matrigel transwell system.

\section{MATERIAL AND METHODS}

\section{Synovial tissue samples}

Synovial tissue was obtained from 56 patients ( 30 with RA, 17 with OA, nine with avascular necrosis (AVN) or fractures) at joint replacement surgery or synovectomy. All patients with RA met the criteria of the American College of Rheumatology. Tissue was harvested by an orthopaedic surgeon and collected in sterile phosphate buffered saline (PBS).

Connective tissue and fat were removed and tissue was digested with collagenase IA ( $1 \mathrm{mg} / \mathrm{ml}$; Sigma, St Louis, MO, USA) for at least two hours at $37^{\circ} \mathrm{C}$.

Cells were separated from the tissue using a $200 \mu \mathrm{m}$ filter (NPBI, Emmer-Compascuum, The Netherlands) and cultured in $75 \mathrm{~cm}^{2}$ culture flasks (Cellstar, Greiner, Alphen aan de Rijn, The Netherlands) with Iscove's modified Dulbecco's medium (IMDM; Biowitthaker, Verviers, Belgium) supplemented with glutamax (GibcoBRL, Paisley, UK), penicillin and streptomycin (Boehringer Mannheim, Germany), and $10 \%$ fetal calf serum (FCS; GibcoBRL, Paisley, UK) at $37^{\circ} \mathrm{C}$ and $5 \% \mathrm{CO}_{2}$. When the cells had grown to confluence they were detached with $0.25 \%$ trypsin and split in a 1:3 ratio. For RNA isolation and invasive growth analysis passage 1 or 2 FLS were used. Light microscopy and Giemsa staining indicated that more than $95 \%$ of cells were FLS .

\section{RNA isolation and cDNA synthesis}

One day before RNA isolation, cells were plated at a density of 100000 cells per well (six well flat bottom plate). Total RNA was isolated from FLS using RNAzol B (Campro, Veenendaal, The Netherlands) according to manufacturer's protocol. RNA pellets were resuspended in diethyl pyrocarbonate treated water.

cDNA was synthesised from $1 \mu \mathrm{g}$ total RNA with oligo-dT (GibcoBRL, Paisley, UK) and mouse murine leukaemia virusreverse transcriptase (MLV-RT; GibcoBRL). In short, $1 \mu \mathrm{g}$ RNA and $0.5 \mu \mathrm{g}$ oligo-dT in $11 \mu \mathrm{l}$ water was incubated at $72^{\circ} \mathrm{C}$ for 10 minutes and then put on ice. $1.2 \mathrm{mM}$ dNTPs (GibcoBRL), $10 \mathrm{U}$ RNAsin (Promega, Madison, WI), $5 \mathrm{mM} \mathrm{MgCl}_{2}$ (Perkin-Elmer, Branchburg, NJ, USA), $50 \mathrm{mM} \mathrm{KCl,} 10 \mathrm{mM}$ Tris- $\mathrm{HCl}$ pH 8.3 (PCR buffer II, Perkin-Elmer), and 20 U mouse MLV-RT was added to a final volume of $20 \mu \mathrm{l}$. This mix was incubated at $37^{\circ} \mathrm{C}$ for one hour and $95^{\circ} \mathrm{C}$ for five minutes.

\section{Design of primers and reverse transcriptase-polymerase chain reaction (RT-PCR)}

The sequence of the primers for MMP 1-14,17, and 19 was used according to Konttinen et al. ${ }^{7}$ The sequence of the primers for TIMP-1 was used according to Keyszer et al, ${ }^{8}$ and for TIMP-2 according to Sodin-Semrl et al. ${ }^{9}$

PCR amplification for MMP 1-12, 14, 17, and 19, cathepsin $\mathrm{K}$, and TIMP-2 was performed using $1 \mu \mathrm{l}$ cDNA mix and 0.2 $\mu \mathrm{M}$ of primers for the proteinase under investigation or $\beta$-actin, $100 \mu \mathrm{M}$ of dNTP, 2 U TAQ polymerase (Perkin-Elmer), $50 \mathrm{mM} \mathrm{KCl}, 10 \mathrm{mM}$ Tris- $\mathrm{HCl} \mathrm{pH} \mathrm{8.3,} \mathrm{and} 1.5 \mathrm{mM} \mathrm{MgCl}_{2}$ to a total volume of $50 \mu \mathrm{l}$. PCR amplification for MMP-13 was performed using $0.33 \mu \mathrm{M}$ of primers for MMP-13, $10 \mu \mathrm{M}$ dNTPs, $0.6 \mathrm{U}$ TAQ polymerase, $0.1 \mathrm{mg} / \mathrm{ml}$ bovine serum albumin, 50 $\mathrm{mM} \mathrm{KCl}, 10 \mathrm{mM}$ Tris- $\mathrm{HCl} \mathrm{pH} \mathrm{8.3,} \mathrm{and} 3.6 \mathrm{mM} \mathrm{MgCl}_{2}$ to a total volume of $30 \mu \mathrm{l}$.

PCR amplification for TIMP- 1 was performed using $1 \mu \mathrm{M}$ of primers for TIMP-1, $50 \mu \mathrm{M}$ dNTPs, 1 U TAQ polymerase, 50 $\mathrm{mM} \mathrm{KCl}, 10 \mathrm{mM}$ Tris- $\mathrm{HCl} \mathrm{pH} 8.3$, and $1.5 \mathrm{mM} \mathrm{MgCl}_{2}$ to a total volume of $50 \mu \mathrm{l}$. The reaction was run in a thermal cycler
(Perkin-Elmer 9700 or Perkin-Elmer 2400, Branchburg, NJ, USA) for 25 cycles (TIMP-1), 30 cycles (TIMP-2), or 40 cycles (MMPs and cathepsin $\mathrm{K}$ ) for one minute denaturation at $95^{\circ} \mathrm{C}$, one minute annealing at the optimal temperature, one minute extension at $72^{\circ} \mathrm{C}$, and finally, 10 minutes' extra extension for the last cycle. The optimal temperatures were $58^{\circ} \mathrm{C}(\mathrm{MMP}-3$, -11 , cathepsin-K), $60^{\circ} \mathrm{C}$ (MMP-14), $62^{\circ} \mathrm{C}$ (MMP-1, -2, -7, -9, $-10,-12,-13,-19$, TIMP-1), and $64^{\circ} \mathrm{C}$ (MMP-8, -17, TIMP-2). Samples without reverse transcriptase were used as a negative control to exclude contamination with genomic DNA.

PCR products were run on gel electrophoresis using a $2 \%$ agarose gel (Roche, Mannheim, Germany) with ethidium bromide, and results were visualised with ultraviolet light.

\section{Invasiveness of FLS in Matrigel matrix}

The transwells in the transwell plates $(6.5 \mathrm{~mm}$ diameter, 8.0 $\mu \mathrm{m}$; Costar, Cambridge NY, USA) were coated with paraffin to avoid meniscus formation.

The Matrigel (Matrigel basement membrane matrix, Becton Dickinson, USA) was diluted in IMDM to $0.375 \mathrm{mg} / \mathrm{ml}$. Thereafter the transwells were preincubated with $100 \mu \mathrm{l}$ IMDM for 30 minutes at $37^{\circ} \mathrm{C}$ and, after removal of the medium, coated overnight with $100 \mu \mathrm{l}$ of $0.375 \mathrm{mg} / \mathrm{ml}$ Matrigel in IMDM in a full functioning laminar flow cabinet.

The next day the Matrigel coated wells were preincubated with $100 \mu \mathrm{l}$ IMDM for one hour at $37^{\circ} \mathrm{C}$. After removal of the medium, $200 \mu \mathrm{l}$ of $100000 \mathrm{FLS} / \mathrm{ml}$ in IMDM was seeded in the inner well of the transwell system. In the outer wells $900 \mu \mathrm{l}$ IMDM $/ 10 \% \mathrm{FCS} / 10 \%$ human serum was pipetted and the transwells were incubated for three days at $37^{\circ} \mathrm{C}$ and $5 \% \mathrm{CO}_{2}$.

After three days, the cells were fixed with $2 \%$ glutaraldehyde in PBS for 30 minutes at room temperature. After removal of the glutaraldehyde and subsequently washing with PBS, the cells were stained with a crystal violet solution for 30 minutes at room temperature. The wells were thoroughly washed with water and the cells that did not invade through the Matrigel and the transwell membrane were removed by cleaning the inner wells of the transwell system with a cotton bud. The number of cells that had grown through the matrix and the transwell membrane was counted under a light microscope. All experiments were done in duplicate.

\section{Rate of proliferation}

FLS were seeded at a density of 5000 cells per well ( 12 well flat bottom plate) and cultured in $1 \mathrm{ml}$ of IMDM/10\% FCS. After days $3,7,10,14$, and 17 the cells were trypsinised and counted in a counting chamber. The cells were stained with trypan blue to exclude dead cells.

From the data obtained, growth curves were established and the rate of proliferation was determined from the steepest slope.

For $\left[{ }^{3} \mathrm{H}\right]$ thymidine incorporation, cells were cultured as described above for cell counting. After three and seven days $0.5 \mu \mathrm{Ci} /$ well $\left[{ }^{3} \mathrm{H}\right]$ thymidine was added and the plates were incubated at $37^{\circ} \mathrm{C}$. After four hours, $\left[{ }^{3} \mathrm{H}\right]$ thymidine incorporation was stopped and the cells were washed twice with $1 \mathrm{ml}$ PBS, then with $1 \mathrm{ml} \mathrm{10 \%} \mathrm{trichloroacetic} \mathrm{acid} \mathrm{(TCA),} \mathrm{and} \mathrm{again}$ twice with $2 \mathrm{ml}$ PBS. Plates were kept at $-20^{\circ} \mathrm{C}$.

$0.5 \mathrm{ml} 0.3 \mathrm{M} \mathrm{NaOH}$ was added to each well and incubated for 30 minutes at room temperature. Then $10 \mathrm{ml}$ emulsifier save (Packard) was added and samples were counted using a tricarb scintillation counter for three minutes for each sample.

\section{Measurement of protein levels of MMP-1 and MMP-2}

To measure quantitatively the protein levels of MMP-1 and MMP-2 an enzyme linked immunosorbent assay (ELISA) was performed according to the manufacturer's protocol with an ELISA kit from Amersham Pharmacia Biotech (UK). The samples for MMP-1 were tested undiluted and those for MMP-2 were diluted 50 times. In total, 34 samples were used in duplicate. 


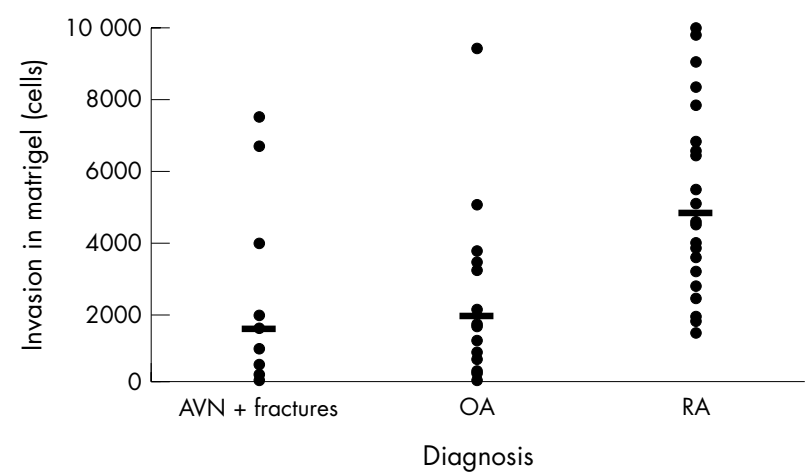

Figure 1 Invasive growth in relation to diagnosis. Invasion of FLS in Matrigel matrix was measured in a transwell system. Three days after seeding on matrix the number of FLS grown through Matrigel and transwell membrane was counted. Shown is the number of cells grown through the Matrigel and the transwell membrane. RA $v O A$ : $p<0.001 ; R A \vee A V N+$ fractures: $p=0.014 ; O A \vee A V N+$ fractures: $p=0.833$.

\section{Statistical analysis}

Statistical analysis was carried out with the aid of SPSS 8.0 software. $p$ Values were estimated using the Mann-Whitney test for unpaired groups. In this article 16 different mRNA species were tested to see if they correlated with the number of cells on the filter. Of these mRNA species, mRNA encoding MMP-2 was always present, thus this variable was excluded from the analysis.

To test if correction for multiple testing should be applied, an initial analysis of the possible correlation between variables was performed. A Spearman's correlation test was performed that yielded a significant correlation between a large number of enzymes. Thus it was concluded that the problem of multiple testing was best approached by a principal component analysis.

\section{RESULTS}

\section{Patients}

The median age of the patients with RA was 62.5 years (mean $63.4 ; 25-75 \%$ interquartile range (IQR) $57.3-74.3 ; n=30$ ), of the patients with OA 70 years (mean $65.5 ; 25-75 \%$ IQR $60.5-$ $72 ; \mathrm{n}=17$ ), and of the patients with AVN 63 years (mean 61.7; 25-75\% IQR 49.5-73.5; $\mathrm{n}=9$ ). The median disease duration of the patients with RA was 14.5 years (mean $15.4 ; 25-75 \%$ IQR $11.8-20 ; \mathrm{n}=18$ ).

\section{Comparison of invasiveness of FLS obtained from different patients}

The number of cells from patients with RA that invaded the Matrigel layer and were attached to the lower side of the filter was: median 4788 (mean 5255; 25-75\% IQR 2709-7778; $\mathrm{n}=30$ ); for the patients with OA, median 1875 (mean 2566; 25-75\% IQR 721-3708; $\mathrm{n}=17, \mathrm{p}<0.001)$; and for the FLS from the patients with AVN, median 1530 (mean 2586; 25-75\% IQR 333-5310; $\mathrm{n}=9, \mathrm{p}=0.014$ and $\mathrm{p}=0.833$ (RA $v$ AVN and OA $v$ AVN respectively) (fig l).

To determine whether these results were caused by a different rate of proliferation of RA FLS, OA FLS, and AVN FLS, the rate of proliferation was measured by counting the number of cells after $3,7,10$, and 14 days and determining the growth curve. The median rate of proliferation of RA FLS was 0.27 per day (mean $0.27 ; 25-75 \%$ IQR $0.24-0.32 ; \mathrm{n}=30$ ) compared with OA FLS 0.22 per day (mean $0.22 ; 25-75 \%$ IQR $0.19-0.26$; $\mathrm{p}=0.012, \mathrm{n}=17)$ and FLS from AVN and fractures 0.25 per day (mean 0.23; 25-75\% IQR 0.19-0.30; RA $v$ AVN: $\mathrm{p}=0.242$; OA $v$ AVN: $p=0.533 ; n=9$ ). No correlation was found between the rate of proliferation and the invasiveness of the FLS (fig 2). Because Matrigel contains several growth factors which might be released upon digestion of matrix by proteinases the rate of

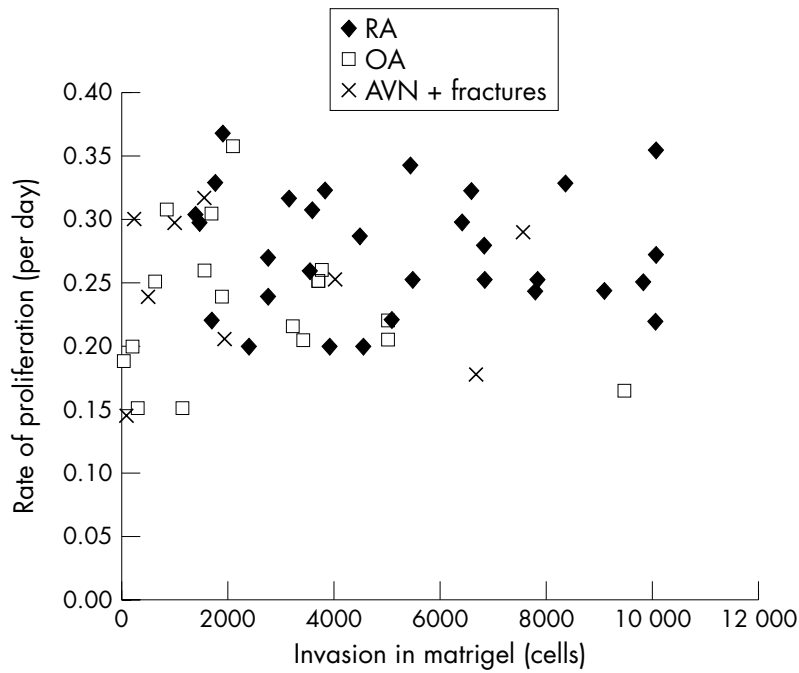

Figure 2 Correlation between rate of proliferation and invasive growth. A total of $5000 \mathrm{FLS}$ were cultured for seven days on IMDM/10\% FCS. After seven days, the FLS were counted and the rate of proliferation was calculated and related to invasive growth. RA $v$ OA: $p=0.012 ; R A \vee A V N+$ fractures: $p=0.242 ; O A \vee A V N+$ fractures: $p=0.533$.

proliferation was also studied when cells were grown on Matrigel. Cells grown on Matrigel had a higher rate of proliferation than cells grown in 10\% FCS in normal tissue culture dishes, but still no correlation between rate of proliferation and invasiveness existed (data not shown).

To measure the rate of proliferation we seeded a number of cells and determined the growth curve by counting the cells after a number of days. To test whether this technique gives an accurate view of the rate of proliferation, the incorporation of $\left[{ }^{3} \mathrm{H}\right]$ thymidine was also analysed. A significant correlation existed between the results obtained with these two techniques (data not shown) and it was concluded that counting the number of cells measures the rate of proliferation accurately.

\section{Role of MMPs, cathepsin-K, and TIMPs in FLS}

To investigate whether the expression of certain MMPs was related to the invasive behaviour of the FLS, the expression of MMPs was tested in FLS with RT-PCR. The level of expression of MMPs, cathepsin-K, and TIMPs was related to the expression of a household gene, $\beta$-actin, primers of which were in the same PCR mix.

Table 1 shows that FLS that expressed MMP-1, MMP-3, or MMP-10 were significantly more invasive (median number of invasive cells $3835,4248,4990$, respectively) than cells that marginally expressed or did not express MMP-1, MMP-3, or MMP-10 (1605, bivariate Mann-Whitney U test $p=0.03 ; 1970$, bivariate Mann-Whitney $U$ test $p=0.004 ; 2360$, bivariate Mann-Whitney $U$ test $p=0.012$, respectively). Expression of MMP-9 showed a trend towards higher expression in more invasive cells $(p=0.066)$. Expression of the other MMPs and cathepsin K did not show a significant relationship with invasive growth.

To avoid the issue of multiple testing we first tested whether the expression of MMPs, cathepsin K, and TIMPs was related to each other. This was the case, therefore a simple Bonferroni correction (the $\mathrm{p}$ value divided by the number of independent tests that were analysed using this dataset) could not be performed. To correct for multiple testing, as the tests performed on this dataset were not independent, a principal components analysis was performed, that yielded two components. Subsequently, an analysis of variance was performed, in which the two components were the predictors and the number of cells 
Table 1 Average invasiveness in relation to expression of MMPs, cathepsin-K, and TIMP-1 and TIMP-2

\begin{tabular}{llll}
\hline & Average invasiveness & & \\
\cline { 1 - 2 } & $\begin{array}{l}\text { Low expression } \\
\text { median (mean [IQR], n) }\end{array}$ & $\begin{array}{l}\text { High expression } \\
\text { median (mean [IQR], n) }\end{array}$ & $\begin{array}{l}\text { Mann-Whitney } \\
\text { test (p value) }\end{array}$ \\
\hline MMP-1 & $1605(2663[418-3916], 14)$ & $3835(4458[1867-6679], 42)$ & 0.03 \\
MMP-2 & $0(0[0-0], 0)$ & $3504(4009[1578-6486], 56)$ & - \\
MMP-3 & $1970(2730[740-4581], 26)$ & $4248(5118[2239-7943], 30)$ & 0.004 \\
MMP-7 & $3504(4001[1545-6408], 54)$ & $4247(4247[1843-6650], 2)$ & 0.844 \\
MMP-8 & $3523(3995[1668-6448], 53)$ & $1413(4259[1365-10000], 3)$ & 0.810 \\
MMP-9 & $3375(3578[1245-5203], 41)$ & $5050(5190[2695-7500], 15)$ & 0.066 \\
MMP-10 & $2360(3411[1125-5400], 39)$ & $4990(5383[3280-8070], 17)$ & 0.012 \\
MMP-1 1 & $3504(3996[1545-6409], 54)$ & $4358(4358[1915-6800], 2)$ & 0.717 \\
MMP-12 & $3504(3903[1535-6141], 52)$ & $4855(5388[2179-9131], 4)$ & 0.396 \\
MMP-13 & $3599(3942[1377-6486], 44)$ & $3133(4254[1996-6250], 12)$ & 0.576 \\
MMP-14 & $3774(4026[1660-6650], 27)$ & $3185(3994[1540-6448], 29)$ & 0.812 \\
MMP-17 & $3133(3731[1516-5413], 34)$ & $3708(4439[1639-6975], 22)$ & 0.45 \\
MMP-19 & $3599(3663[1265-5104], 34)$ & $3335(4545[1801-7028], 22)$ & 0.322 \\
Cathepsin-K & $1915(3295[205-7765], 3)$ & $3523(4050[1605-6448], 53)$ & 0.654 \\
TIMP-1 & $2010(3273[1007-6005], 12)$ & $3675(4192[1728-6650], 43)$ & 0.271 \\
TIMP-2 & $2498(2464[1439-3766], 8)$ & $3599(4267[1581-6736], 48)$ & 0.198 \\
\hline
\end{tabular}

Table 2 Comparison of expression of MMPs, cathepsin-K, and TIMP-1 and TIMP-2 and diagnosis

\begin{tabular}{llllll}
\hline & \multicolumn{2}{l}{ RA expression } & \multicolumn{2}{c}{ OA expression } \\
\cline { 2 - 3 } \cline { 5 - 6 } & Low $(\mathrm{n})$ & High $(\mathrm{n})$ & & Low $(\mathrm{n})$ & High $(\mathrm{n})$ \\
\hline MMP-1 & 3 & 27 & 7 & 10 \\
MMP-2 & 0 & 30 & 0 & 17 \\
MMP-3 & 11 & 19 & 9 & 8 \\
MMP-7 & 29 & 1 & 17 & 0 \\
MMP-8 & 27 & 3 & 17 & 0 \\
MMP-9 & 18 & 12 & 16 & 1 \\
MMP-10 & 20 & 10 & 10 & 7 \\
MMP-1 & 29 & 1 & 17 & 0 \\
MMP-12 & 27 & 3 & 16 & 1 \\
MMP-13 & 22 & 8 & 14 & 3 \\
MMP-14 & 13 & 17 & 9 & 8 \\
MMP-17 & 19 & 11 & 9 & 8 \\
MMP-19 & 16 & 14 & 11 & 6 \\
Cathepsin-K & 1 & 29 & 0 & 17 \\
TIMP-1 & 6 & 24 & 4 & 12 \\
TIMP-2 & 3 & 27 & 2 & 15 \\
\hline
\end{tabular}

on the filter was the dependent variable. This yielded a value of $\mathrm{p}=0.024(\mathrm{~F}=4)$. So, it can be concluded that a significant correlation between expression of degradative enzymes and invasion exists.

\section{Expression of MMPs, cathepsin-K, and TIMPs in relation to disease}

The relation between the diagnosis for the patient from whom the FLS were harvested and expression of MMPs, cathepsin-K, and TIMPs in FLS was also analysed. Table 2 shows a relationship between the expression of MMP-1, MMP-3, MMP-9, and MMP-10 and the various disease states. The odds ratios for expression of MMP-1, MMP-3, MMP-9, and MMP-10 for the diagnosis RA or OA were $6.5(\mathrm{p}=0.013) ; 1.9 ; 10.7(\mathrm{p}=0.013)$; and 1.4, respectively (table 3 ). There was no obvious relationship between expression of the other MMPs, cathepsin-K, or TIMPs and the diagnosis.

\section{Correlation between mRNA and protein levels of MMP-1 and 2}

To test if a correlation existed between mRNA of MMPs and the protein level of MMPs an ELISA was done for MMP-1 and
Table 3 Odds ratios for the relation between diagnosis and expression of MMP-1, MMP-3, MMP-9, and MMP-10

\begin{tabular}{lrrrl}
\hline & OA & RA & OR & p Value \\
\hline MMP-1 & 7 & 3 & 6.5 & 0.013 \\
$\quad$ Low expression & 10 & 27 & & \\
$\quad$ High expression & 9 & 11 & & \\
$\begin{array}{l}\text { MMP-3 } \\
\text { Low expression }\end{array}$ & 8 & 19 & & \\
$\quad$ High expression & 16 & 18 & & \\
$\begin{array}{l}\text { MMP-9 } \\
\text { Low expression }\end{array}$ & 1 & 12 & & \\
$\quad$ High expression & 10 & 20 & & 0.013 \\
MMP-10 & 7 & 10 & & \\
Low expression & & & & \\
High expression & & & & \\
\hline
\end{tabular}

MMP-2; the results obtained with the ELISA were comparable with the results obtained with RT-PCR (data not shown).

\section{DISCUSSION}

This study shows that the FLS harvested from patients with RA exhibit a significantly more invasive behaviour in a transwell system than FLS from patients with OA. This transwell invasion system was described previously as a model for tumour metastasis and showed a correlation with lung colonisation in vivo. ${ }^{10}$

The in vitro invasion data shown here are consistent with a study by Müller-Ladner et al, ${ }^{4}$ in which isolated FLS from patients with RA were more invasive than FLS from patients with OA when co-implanted with normal human cartilage in SCID mice. In this last study the FLS kept their transformed appearance and produced proteases at the site of invasion. ${ }^{4}$

In our study we show that FLS from RA have a $25 \%$ higher rate of proliferation than OA. However, the lack of correlation between the rate of proliferation and the invasive growth in Matrigel matrix indicates that this higher rate of proliferation is not an explanation for the invasive behaviour of FLS from patients with RA.

The higher rate of proliferation is also consistent with an earlier study of Qu et $a l,{ }^{3}$ who found that the proliferation markers, proliferating cell nuclear antigen, c-myc, and nucleolar organising region were more abundant in FLS from 
patients with RA than in FLS from patients with OA. ${ }^{3}$ Although a structural basis for this increased rate of proliferation was proposed, these data were not confirmed in replication studies. ${ }^{11-16}$ It is known that proteases can degrade ECM proteins, allowing the invasion of FLS in cartilage. Now we have shown that FLS that express MMP-1, MMP-3, (MMP-9), or MMP-10 are significantly more invasive than cells that do not express these MMPs. No significant relationship was found between invasive growth and expression of the other MMPs, cathepsin-K, and TIMPs. The expression of MMP-1 and MMP-9 was significantly higher in patients with RA than in patients with OA. MMP-3 and MMP-10 showed a non-significant correlation with RA.

The expression of MMPs in RA has been extensively researched. In these studies mRNA for MMP-1, MMP-3, MMP-13, and TIMP were found in the lining layer cells, ${ }^{17-29}$ which consist mainly of FLS and macrophages. MMP-1, MMP-3, and TIMP were also found in some sublining layer cell populations. ${ }^{17-19}$ Moreover, MMP-3 knockout mice show no joint erosions at two weeks after induction of antigen-induced arthritis, ${ }^{30}$ implying a role for this protease in the destruction of cartilage. The expression of MMP-9 and MMPs 14-17 was also found to be greater in synovial tissue of patients with RA than in that of controls. ${ }^{31-33}$ MMP-8 was reported to be expressed by FLS in the rheumatoid synovial membrane and its expression is up regulated after treatment with tumour necrosis factor $\alpha .^{34}$

In synovium, the expression of MMP-1 to MMP-20 from patients with RA was compared with FLS from trauma patients. $^{7}$ In this study it was found that MMP-2, MMP-3, MMP-11, and MMP-19 were constitutively expressed. MMP-1, MMP-9, and MMP-14 were expressed in all RA samples and in $55-80 \%$ of trauma samples. MMP- 13 and MMP- 15 were expressed exclusively in RA samples, and MMP- 8 was rarely found in both RA and trauma. MMP-20 was absent in all samples. The other MMPs (MMP-7, -10, -12, -16, and -17) had an intermediate pattern of expression. ${ }^{7}$

No previous studies have directly studied the expression of MMPs in FLS, neither has expression been correlated with invasive behaviour of these cells. In this study the expression of MMPs is compared with the invasive behaviour of FLS in an in vitro invasion system. Furthermore, the expression of MMPs was compared with a diagnosis of RA or OA.

In another study adenoviral gene transfer of TIMP-1 and TIMP-3 was used to test the effect of MMP inhibitors on the invasiveness of FLS in an in vitro invasion model and in vivo in an SCID mouse model..$^{35}$ Adenoviral gene transfer showed that TIMP-1 and TIMP-3 significantly decreased invasiveness in both these systems as compared with Adcontrol-transduced FLS. Moreover, marimastat, a synthetic inhibitor of MMPs was shown to decrease the invasiveness of FLS in vitro. ${ }^{35}$ In summary, all these data point to a pivotal role for MMPs in the invasive behaviour of FLS in RA.

A limitation in the interpretation of the data in our study is that the expression of MMPs is determined on the mRNA level with RT-PCR, whereas MMPs need cleavage of the propeptide for full activation. Thus, RT-PCR cannot distinguish between inactive and active MMPs.

Matrigel consists, in addition to other components of the ECM, particularly of collagen type IV, whereas human cartilage consists mainly of collagen type II and the proteoglycan aggrecan. MMP-2, -3, -7, -9, and -10 can degrade collagen type IV. ${ }^{36-41}$ In this study, no relation between invasion and expression of MMP-2 and MMP-7 was found, but a significant relationship existed between invasion and expression of MMP-3 and MMP-10 and there was a trend towards a relationship for MMP-9. In this study the expression of different enzymes was correlated with one variable (the number of cells grown through the matrix). Because the expression of the enzymes tested correlated with each other, the method to control for multiple testing was a principal component analysis. With this analysis a significant result was still obtained.
In conclusion, a relationship exists, between the expression of MMP-1, MMP-3, MMP-9, and MMP-10 and invasive growth in a Matrigel transwell system. This relationship is also seen between the expression of MMP-1 and MMP-9 and a diagnosis of RA.

\section{ACKNOWLEDGEMENTS}

The authors thank Professor J C van Houwelingen for his assistance with the statistics, especially those concerning multiple testing, and $\mathrm{J}-\mathrm{P}$ Bayley for critically reading the manuscript.

\section{Authors' affiliations}

T C A Tolboom, E Pieterman, W H van der Laan, R E M Toes, A L Huidekoper, F C Breedveld, T W J Huizinga, Department of Rheumatology, Leiden University Medical Centre, Leiden, The Netherlands

W H van der Laan, Gaubius laboratory, TNO Prevention and Health, Leiden, The Netherlands

R G H H Nelissen, Department of Orthopaedic Surgery, Leiden

University Medical Centre, Leiden, The Netherlands

\section{REFERENCES}

1 Firestein GS. Invasive fibroblast-like synoviocytes in rheumatoid arthritis. Passive responders or transformed aggressors? Arthritis Rheum 1996:39:1781-90.

2 Pap T, van der Laan WH, Aupperle KR, Gay RE, Verheijen JH, Firestein GS, et al. Modulation of fibroblast-mediated cartilage degradation by articular chondrocytes in rheumatoid arthritis. Arthritis Rheum 2000;43:2531-6.

3 Qu Z, Garcia CH, O'Rourke LM, Planck SR, Kohli M, Rosenbaum JT. Local proliferation of fibroblast-like synoviocytes contributes to synovial hyperplasia. Arthritis Rheum 1994;37:212-20.

4 Müller-Ladner U, Kriegsmann J, Franklin BN, Matsumoto S, Geiler T, Gay RE, et al. Synovial fibroblasts of patients with rheumatoid arthritis attach to and invade normal human cartilage when engrafted into SCID mice. Am J Pathol 1996; 149:1607-15.

5 Parsons SL, Watson SA, Brown PD, Collins HM, Steele RJC. Matrix metalloproteinases. Br J Surg 1997;84:160-6

6 Hummel KM, Petrow PK, Franz JK, Müller-Ladner U, Aicher WK, Gay $R E$, et al. Cysteine proteinase cathepsin $K$ mRNA is expressed in synovium of patients with rheumatoid arthritis and is detected at sites of synovial bone destruction. J Rheumatol 1998;25:1887-94.

7 Konttinen YT, Ainola M, Valleala H, Ma J, Ida H, Mandelin J, et al. Analysis of 16 different matrix metalloproteinases (MMP-1 to MMP-20) in the synovial membrane: different profiles in trauma and rheumatoid arthritis. Ann Rheum Dis 1999;58:691-7.

8 Keyszer G, Redlich A, Häupl T, Zacher J, Sparmann M, Ungethüm U, et al. Differential expression of cathepsins $B$ and $L$ compared with matrix metalloproteinases and their respective inhibitors in rheumatoid arthritis and osteoarthritis. A parallel investigation by semi-quantitative reverse transcriptase-polymerase chain reaction and immunohistochemistry. Arthritis Rheum 1998;41:1378-87.

9 Sodin-Semrl S, Taddeo B, Tseng D, Varga J, Fiore S. Lipoxin A4 inhibits IL-1 $\beta$-induced IL-6, II-8, and matrix metalloproteinase-3 production on human synovial fibroblasts and enhances synthesis of tissue inhibitors of metalloproteinases. J Immunol 2000; 164:2660-6.

10 Repesh LA. A new in vitro assay for quantitating tumor cell invasion. Invasion Metastasis 1989;9:192-208.

11 Aupperle KR, Boyle DL, Hendrix M, Seftor EA, Zvaifler NJ, Barbosa M, et al. Regulation of synoviocyte proliferation, apoptosis, and invasion by the p53 tumour suppressor gene. Am J Pathol 1998;152:1091-8.

12 Firestein GS, Echeverri F, Yeo M, Zvaifler NJ, Green DR. Somatic mutations in the $\mathrm{p} 53$ suppressor gene in rheumatoid arthritis synovium Proc Natl Acad Sci USA 1997:94:10895-900.

13 Rème T, Travaglio A, Gueydon E, Adla L, Jorgensen C, Sany J. Mutations of the $\mathrm{p} 53$ tumour suppressor gene in erosive theumatoid synovial tissue. Clin Exp Immunol 1998; 111 1:353-8.

14 Kullmann F, Judex M, Neudecker I, Lechner S, Jüsten H-P, Green DR, et al. Analysis of the p53 tumor suppressor gene in rheumatoid arthritis synovial fibroblasts. Arthritis Rheum 1999;42:1594-600.

15 Aicher WK, Heer AH, Trabandt A, Bridges SL, Schroeder HW, Gay RE, et al. Overexpression of zinc-finger transcription factor Z-225/Egr-1 in synoviocytes from rheumatoid arthritis patients. J Immunol 1994; 152:5940-8.

16 Sarkissian M, Lafyatis R. Integrin engagement regulates proliferation and collagenase expression of rheumatoid synovial fibroblasts. J Immunol 1999; 162:1772-9.

17 Firestein GS, Paine MM, Littman BH. Gene expression (collagenase, tissue inhibitor of metalloproteinases, complement, and HLA-DR) in rheumatoid arthritis and osteoarthritis synovium. Quantitative analysis and effect of intraarticular corticosteroids. Arthritis Rheum 1991;34:1094-105.

18 Gravallese EM, Darling JM, Ladd AL, Katz JN, Glimcher LH. In situ hybridisation studies of stromelysin and collagenase messenger RNA expression in rheumatoid synovium. Arthritis Rheum 1991;34:1076-84. 
19 Case JP, Lafyatis R, Remmers EF, Kumkumian GK, Wilder RL. Transin/ stromelysin expression in rheumatoid synovium. A transformation-associated metalloproteinase secreted by phenotypically invasive synoviocytes. Am J Pathol 1989;135:1055-64.

20 McCachren SS. Expression of metalloproteinases and metalloproteinase inhibitor in human arthritic synovium. Arhtritis Rheum 1991;34:108593.

21 Firestein GS, Paine MM. Stromelysin and tissue inhibitor of metalloproteinases gene expression in rheumatoid arthritis synovium. Am J Pathol 1992;140:1309-14.

22 McCachren SS, Haynes BF, Niedel JE. Localization of collagenase mRNA in rheumatoid arthritis synovium by in situ hybridisation histochemistry. J Clin Immunol 1990; 10:19-27.

23 Sawai T, Murakami K, Ohtani Y, Kurkinnen M, Kyogoku M, Hayashi M. Stromelysin synthesizing cells in the synovial tissues of rheumatoid arthritis demonstrated by in situ hybridisation and immunohistochemical methods. Tohoku J Exp Med 1990; 160:285-6.

24 Okada Y, Takeuchi N, Tomita K, Nakanishi I, Nagase H. Immunolocalisation of matrix metalloproteinase 3 (stromelysin) in rheumatoid synovioblasts (B cells): correlation with rheumatoid arthritis. Ann Rheum Dis 1989:48:645-53.

25 Tetlow LC, Lees M, Ogata Y, Nagase H, Woolley DE. Differential expression of gelatinase B (MMP-9) and stromelysin-1 (MMP-3) by rheumatoid synovial cells in vitro and in vivo. Rheumatol In 1993; 13:53-9

26 Tak PP, Bresnihan B. The pathogenesis and prevention of joint damage in rheumatoid arthritis. Advances from synovial biopsy and tissue analysis. Arthritis Rheum 2000;43:2619-33.

27 Wernicke D, Seyfert C, Hinzmann B, Gromnica-lhle E. Cloning of collagenase 3 from the synovial membrane and its expression in rheumatoid arthritis and osteoarthritis. J Rheumatol 1996;23:590-5.

28 Schulze-Westhoff C, Freudiger D, Petrow P, Seyfert C, Zacher J, Kriegsmann J, et al. Characterization of collagenase 3 (matrix metalloproteinase 13) messenger RNA expression in the synovia membrane and synovial fibroblasts of patients with rheumatoid arthritis. Arthritis Rheum 1999;42:1517-27.

29 Lindy O, Konttinen YT, Sorsa T, Ding Y, Santavirta S, Ceponis A, et al. Matrix metalloproteinase 13 (collagenase 3) in human rheumatoid synovium. Arthritis Rheum 1997;40:1391-9.
30 v Meurs J, v Lent $\mathrm{P}$, Stoop R, Holthuysen A, Singer I, Bayne E, et al. Cleavage of aggrecan at the $\mathrm{ASN}^{341}-\mathrm{PHE}^{342}$ site coincides with the initiation of collagen damage in murine antigen-induced arthritis. Arthritis Rheum 1999;42:2074-84.

31 Ahrens D, Koch AE, Pope RM, Stein-Picarella M, Niedbala M. Expression of matrix metalloproteinase 9 (96-kd gelatinase B) in human rheumatoid arthritis. Arthritis Rheum 1996;39:1576-87.

32 Pap T, Shigeyama Y, Kuchen S, Fernihough JK, Simmen B, Gay RE, et al. Differential expression pattern of membrane-type matrix metalloproteinases in rheumatoid arthritis. Arthritis Rheum 2000;43:1226-32.

33 Yamanaka H, Makino K-I, Takizawa M, Nakamura H, Fujimoto N, Moriya $\mathrm{H}$, et al. Expression and tissue localization of membrane-types 1 , 2 , and 3 matrix metalloproteinases in rheumatoid synovium. Lab Invest 2000;80:677-87

34 Hanemaaijer $\mathbf{R}$, Sorsa T, Konttinen YT, Ding $Y$, Sutinen $M$, Visser $H$, et al. Matrix metalloproteinase-8 is expressed in rheumatoid synovial fibroblasts and endothelial cells. J Biol Chem 1997;272:31504-9.

35 Van der Laan WH, Quax PH, Seemayer CA, Huisman LG, Pieterman EJ, Grimbergen JM, et al. Gene transfer of TIMP-1 and TIMP-3 inhibits proliferation of RA synovial fibroblasts and reduces cartilage invasion in the SCID mouse model of RA. ACR abstract (in press).

36 Nagase $\mathbf{H}$. Human stromelysins 1 and 2. Methods Enyzmo 1995;248:449-70.

37 Murphy G, Crabbe T. Gelatinases A and B. Methods Enzymol 1995:248:470-84

38 Nagase H, Ogata Y, Suzuki K, Enghild JJ, Salvesen G. Substrate specificities and activation mechanisms of matrix metalloproteinases. Biochem Soc Trans 1991; 19:715-18

39 Nagase H, Okada Y. Proteinases and matrix degradation. In: Kelley WN, Harris ED, Ruddy S, Sledge CB, eds. Textbook of rheumatology. 5th ed. Philadelphia: Saunders, 1997:323-41.

40 Fessler LI, Duncan KG, Fessler JH. Characterization of the procollagen IV cleavage products produced by a specific tumour collagenase. J Biol Chem 1984:259:9783-9.

41 Mott JD, Khalifah RG, Nagase H, Shield CF, Hudson JK, Hudson BG. Nonenzymatic glycation of type IV collagen and matrix metalloproteinase susceptibility. Kidney Int 1997;52:1302-12.

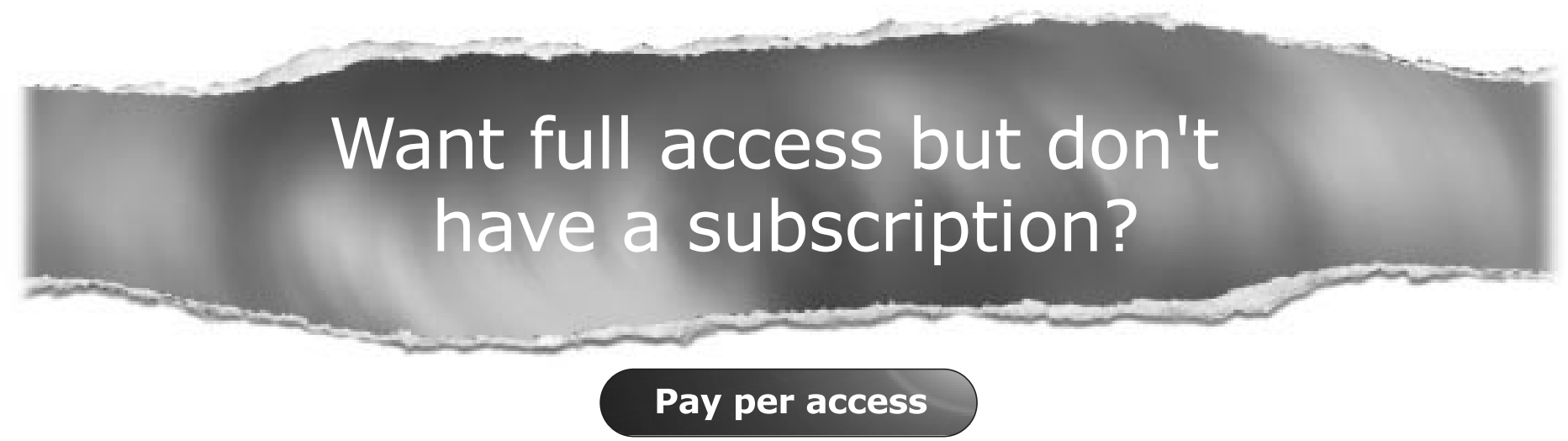

For just US $\$ 25$ you can have instant access to the whole website for 30 days. During this time you will be able to access the full text for all issues (including supplements) available. You will also be able to download and print any relevant pdf files for personal use, and take advantage of all the special features Annals of the Rheumatic Diseases online has to offer.

\section{www.annrheumdis.com}

